\title{
Elder Women's Socio-Economic Problems And Their Impact: A Feminine Perspective On Experiencing Old Age Problems In Karachi, Pakistan
}

\author{
Sakina Riaz \\ Department of Social Work \\ University of Karachi \\ Mahe Darakhshan \\ Department of Media Studies \\ Bahria University \\ Samina Rauf \\ Department of Social Work \\ University of Karachi
}

\begin{abstract}
This study was conducted from the period of October to December 2013 with a selected population of elderly women who belongs to urban and rural areas of Karachi. The aim of the study was to investigate the Socio-economic conditions, health status, psychological condition, living style and also social support mechanisms among the elderly women in both rural and urban areas. Stratified random sampling method was used to collect the data. A sample of 300 female senior citizens was selected from two different communities of two union councils namely, "Jut Lines" and the "Central Jacob Line" of Jamshed Town from urban area and two from Malir town to represent the rural population of Karachi, Pakistan. The respondents were interviewed through a formulated questionnaire that was crosstranslated into Urdu language to determine the participant's socio-economic problems. The study respondents belong to different walks of life and they participated voluntarily in this study. Similar studies are needed to be conducted in other community settings for recommending appropriate changes in public behavior towards elder women problems' in our society.

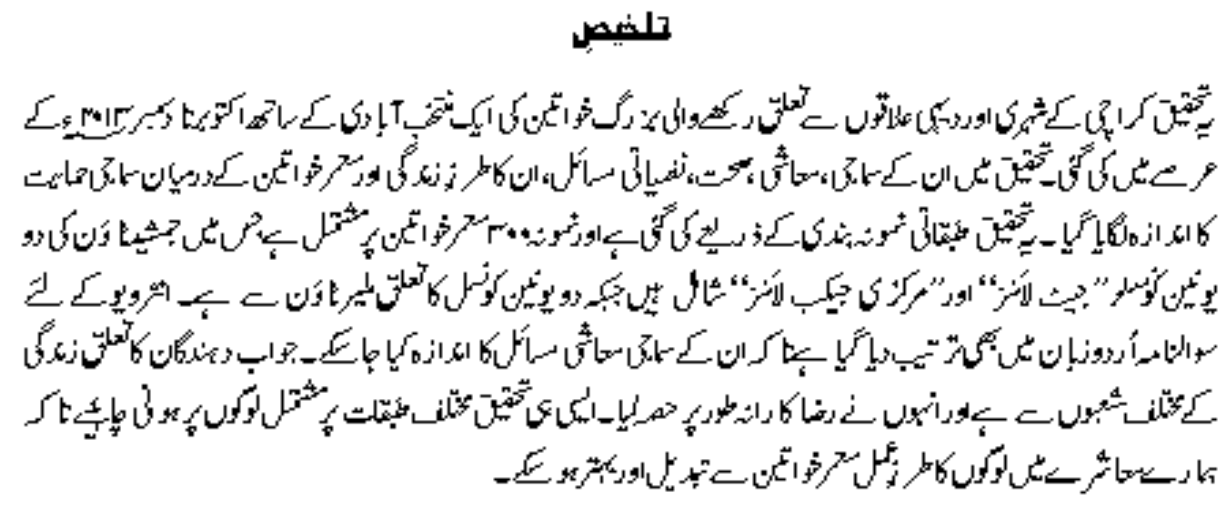


Key Words: Elder Women, Socio- Economic Problems, Impact, Karachi.

\section{Background}

With a growing older population, ageing has become an important issue especially for women in Pakistan. Ageing refers to a decline in the functional capacity of the organs of the human body, which occurs mostly due to physiological transformation, it does not mean that everything has been finished or out -dated but it can be define as a process of deterioration in the functional capacity of an individual that results from structural changes, with advancement of age. Ageing is a series of transition from one set of social roles to another structured by the social system of a society (Niaz et.al. 2009).

If we review the history, it is revealed that women have a low social status as compare to men. Even today, in many cultures of our society, they were considered to be physically weak and intellectually imperfect, requiring the protection of father in infancy and childhood, of husband during their adulthood, and of sons, in their old age. Ironically enough, in modern times, social changes seem to have aggravated the situation. Women's participation in education, remunerative work and community affairs is patently and woefully low. (Archana Kaushik, 2008). The population of the elderly persons has been increasing over the years. As per the UNESCO estimates, the number of the aged (60+) is likely to 590 million in 2005 . The figure will double by 2025 . By 2025 , the world will have more elderly than young people and cross two billion mark by 2050. Pakistan's demographic trends show that between 1990 till 2010, the population aged 60+ years increased by $75.1 \%$. (Gapminder) It is projected that the life expectancy will increase to 72 years by 2023. WHO report (1998) projected that $5.6 \%$ of Pakistan's population was over 60 years of age, with a probability of doubling to $11 \%$ by the year 2025 .It is estimated that in the more developed countries, about 15 percent of the population is of persons 65 years and above compared with nearly $5 \%$ in the less developed countries in the year 2005, and these percentages may be higher if assessed for ages 60 years and above (Population Reference Bureau, 2005). Further, it is expected that South Asia will experience a dramatic increase in its elderly population by nearly nine times between 2010 and 2025, when life expectancy will increase to 75 years for men and 82 years for women (Rehmatullah, 2011).

The feminization of aging is a process that has begun in Pakistan but is not occurring equally throughout the country. This problem is deep rooted and has many dimensions. According to a website, in Pakistan, the process of ageing is well on its way due to declining trends in mortality and fertility levels and an increase in the average span of life in recent decades. Pakistan's life expectancy was increased from 45.6 years in 1950 to 66.8 years in 2008 (Gapminder).Hence, the changing demographics and social trends in terms of shifts from extended to a more nuclear family system has raised concerns about 
the rising old-age dependency ratio and the adequacy of future family support for the elderly (Naushin Mahmood, 2008). Besides, the varying effects of ageing on some major aspects of the society such as health, social security, education, business opportunities, sociocultural activities and family relations (Kocaman, 2007), there are, however, factors which create problems for persons with old age. Among them the most important factor is the changing functions of family institution. Although family has still a central position in addressing emotional and socio-economic needs of them (Hamid Alam, 2013). The ability of persons with old age to cope with the changes of health, income and social activities depend to a great extent on the support the person gets from his/ her family members (Sivamurthy \& Wadakannavar, 2001). Needs of the elderly are hardly met when the total economic dependency of the elderly upon the family is accompanied by the lack of a holistic socioeconomic developmental strategy in the country that targets the welfare of its ageing population (Ali \& Kiani, 2003) Deterioration in health is one of the natural consequences of physiological ageing. People who have had to give up their career because of health concerns often suffer from stress and psychological problems (Strandh, 2000).In an analysis Agrawal (2012) pointed out that elderly who are living alone are likely to suffer more from both chronic illnesses, such as asthma and tuberculosis, and acute illnesses, such as malaria and jaundice, than those elderly who are living with their family, even after controlling for the effects of a number of socio-economic, demographic, environmental and behavioural confounders.

The 1998 Census and the Pakistan Demographic Surveys present valuable information on the socio-economic and demographic distinctiveness of the elderly population. (Afzal, 2000) The ageing process in Pakistan is expected to gain momentum that will narrow the age structure at the base and will enhance the old age dependency ratio (ORD). ${ }^{1}$

Table I

Total Population and Elderly Persons (Aged +60) in Pakistan: 1961-2030 Elderly Population (Million)

\begin{tabular}{|l|c|c|c|c|}
\hline Census Year & Total & Male & Female & Sex Ratio M/F \\
\hline 1961 & 2.92 & 1.68 & 1.24 & 135 \\
\hline 1972 & 4.57 & 2.63 & 1.94 & 135 \\
\hline 1981 & 5.88 & 3.40 & 2.48 & 137 \\
\hline 1998 & 7.34 & 3.99 & 3.35 & 119 \\
\hline $\begin{array}{l}\text { Projected Estimates for } \\
2013\end{array}$ & 11.19 & 5.69 & 5.50 & 103 \\
\hline 2030 & 22.07 & 11.09 & 11.09 & 99 \\
\hline
\end{tabular}

Source: Pakistan (2002) Ageing in Pakistan: A Situation Analysis, Ministry of Social Welfare and Special Education, Islamabad. 
In1999, government of Pakistan designed a National Policy for the promotion of better health of the Elderly. This policy incorporated training of primary care doctors in geriatrics, availability of dental care, domiciliary care, and a multi-tiered system of health care providers for elderly including physical therapists and social workers. "Green Slips" for prescriptions were also made. (Health Systems Profile Pakistan Regional Health Systems Observatory -EMRO). Unfortunately implementation of this policy is still being awaited (Sabeena Jalal et.al, 2012)

Table II

Labour Force Participation Rates (\%)

\begin{tabular}{|l|c|c|c|}
\hline Age Group & Both Sexes & Male & Female \\
\hline $60-64$ & 34.3 & 62.4 & 1.6 \\
\hline $65-69$ & 32.6 & 58.0 & 1.7 \\
\hline $70-74$ & 29.6 & 52.3 & 1.4 \\
\hline $75+$ & 24.9 & 44.5 & 1.2 \\
\hline Total $(\mathbf{6 0}+)$ & $\mathbf{3 0 . 9}$ & $\mathbf{5 5 . 5}$ & $\mathbf{1 . 6}$ \\
\hline
\end{tabular}

Source: 1998 Population Census of Pakistan.

The above-mentioned table shows that the female literacy rate is only 8.9 percent and their work participation is reported as low as 1.6 percent. Furthermore, women from low socioeconomic strata, who have little or no formal education, depend almost exclusively on their male family members. This financial dependence is frequently associated with helplessness, fear and insecurity, and position the women at more vulnerable for poor mental health. Several reports from the United Nations, World Health Organization, and World Bank note that world - wide $70 \%$ of women live in poverty and earn only $10 \%$ of the world's total income (Care, D. M. 2005). As pointed out by Lopez-Claros \& Zahidi, (2005) that "Worldwide, outside of the agricultural sector, in both developed and developing countries, women are still averaging slightly less than $78 \%$ of the wages given to men for the same work, a gap which refuses to close in even the most developed countries". Besides, the varying effects of ageing on some major aspects of the society such as health, social security, education, business opportunities, socio-cultural activities and family relations (Kocaman, 2007) Gender, education, marital status, family structure, income of the family, personal incomes of the respondents, economic and social problems are the important dimensions of social adjustment in old age. (Furdous et.al. 2008).

Although there are numerous studies conducted on the problems of elder women, but unfortunately remain poorly understood and often unclear in our society. Yet, the policy makers have failed to develop employment -oriented budgets or fiscal system especially for elders in Pakistan. These problems are exacerbated by a lifetime of gender based discrimination, often stemming from deep-rooted cultural and social bias. It is compounded by other forms of discrimination based on class, caste, disability, illiteracy, 
unemployment and marital status. Patriarchal hierarchy and access to property rights are also prejudiced. Burdened with household chores for a longer span of time compared to older men, older women do not have time for leisure or recreational activity. Women experience proportionately higher rates of chronic illness and disability in later life than men. Women suffer greater non-communicable diseases and experience lower social and mental health status, especially if they are single and/or widowed. Approximately, over $50 \%$ of women over age 80 are widows. The increase of demographic ageing process in our country has a series of socio-economic problems as well as health problems. Elderly are high users of medical resources. It is estimated that at least 6-7 \% of elderly visiting geriatric clinics at the Aga Khan University Hospital Karachi are living alone with little assistance (Sabzwari et.al., 2010) There is no wide-spread practice of health insurance coverage, hence, population relies on out of pocket expenditure for the treatment of all ailments.(Sabeena et.al., 2012)

The Millennium Development Goals (MDGs) set for 2015 clearly connect women's empowerment with the achievement of global health for all. The key to women's autonomy is considered education and employment (WHO, 2005). Despite global improvements for elder women in the last few decades, lots of efforts are still required for elder women's ability to claim their rights and realize their full potential as citizens in the development of their communities.

\section{Social Theory of Ageing}

Several theories of ageing are developed to observe the ageing process of older adults in society as well as how these processes are interpreted by men and women as they age (Phillipson et.al. 2007). It is recommended that older adults should remain socially active in their later years (Bergstrom et.al. 2000).

Disengagement theory was developed by Cumming and Henry. According to this theory, older adults and society engage in a mutual separation from each other.

Activity theory was developed and elaborated by Cavan, Havighurst, and Albrecht. This theory argues that the more active elderly person are, the greater their satisfaction with life. In order to maintain a positive sense of self, elderly people must substitute new roles for those lost in old age. Exchange theory of ageing views that aged has less power in relation to younger people because they possess fewer resources and continued interaction with the younger becomes more costly.

Role theory argues that role lose accompanies the ageing process. This could be associated with the loss of identity and esteem. Continuity theory argues that the ageing person substitutes new roles for the lost ones, and continues to maintain typical; ways of adapting to the environment. 
Modernization theory argues that the role and status of the aged is inversely related to the level of societal industrialization. This tends to have a distinctly negative impact on the status of the elderly. With modernization comes a decline in small, socially cohesive, tradition-oriented communities. Individualization and the expansion of individual choice tend to weaken the position of the elderly.

Life course Perspective According to this Perspective ageing occurs from birth to death. Ageing involves social, psychological, and biological processes. Additionally, ageing experiences are shaped by cohort historical factors (Hage et.al., 1972)

Age stratification theory: According to this theory, older adults have born during different time periods form cohorts that define "age strata". There are two differences among strata: chronological age and historical experience. This theory examines the movement of successive birth cohorts across time, known as "cohort flow". Each cohort is unique in that it has its own characteristics (e.g. size, gender, and social class distribution). Each experiences particular historical events which affects its member's attitudes and behaviors.

\section{Research Methodology}

This study was carried out among the elderly women living in urban and rural areas of Karachi with the following objectives:

1. To assess the socio-economic and demographic characteristics of elderly women living in urban and ruler areas of Karachi.

2. To examine the social and health problems among the elderly women across different socio-economic groups.

3. To evaluate the interest and activities of elderly women living in urban and rural areas of Karachi.

4. To study the felt needs of the elderly women for the betterment of their quality of life.

\section{Research Questions}

Specifically, this study addresses the following questions.

1. What is the level of poverty among the elderly women?

2. What is the level of illiteracy among the elderly women?

3. How are the senior women being discriminated especially for access to health care treatment when required?

4. What is the need of the elderly women and what problems they are experiencing in their old age? 
To conduct this research work, mix methods research has been used (both qualitative \& quantitative methods were applied for data collection). Primary data has been collected from in depth interview strategy whereas; secondary data has been collected from credible e-books, journal, publications, internet articles and official websites. Considering Karachi the hub of Pakistan, the study was carried out in different urban and ruler communities of Karachi. These communities were selected as one of the oldest and densely populated communities for the sample population. For this study, Two Urban site (two different communities of two union councils namely, "jut lines" and the "central Jacob line" of Jamshed Town) and for Rural representation we choose Malir Town (Jam Goth \& Memon Goth) of Karachi as strata, and the sample will be the elder women using stratified random sampling technique .To ensure representation from all strata, four sampling areas were selected from the urban and rural areas adjacent to the Karachi city. The distribution of respondent is given in Table $\mathbf{I}$.

Table III

Allocation of Sample Stratum

\begin{tabular}{|c|c|c|c|c|c|}
\hline $\begin{array}{l}\text { Karachi } \\
\text { City }\end{array}$ & $\begin{array}{l}\text { Respondents } \\
\text { Background }\end{array}$ & $\begin{array}{c}\text { No. of } \\
\text { Respondent }\end{array}$ & $\begin{array}{l}\text { Area Selected } \\
\text { for the study }\end{array}$ & $\begin{array}{c}\text { No. of } \\
\text { Respondent }\end{array}$ & $\%$ \\
\hline \multirow{2}{*}{$\begin{array}{l}\text { Jamshed } \\
\text { Town }\end{array}$} & \multirow{2}{*}{$\begin{array}{l}\text { Urban } \\
\text { (Group A) }\end{array}$} & \multirow[t]{2}{*}{150} & Jut lines & 55 & $36.6 \%$ \\
\hline & & & $\begin{array}{c}\text { Central Jacob } \\
\text { line }\end{array}$ & 95 & $63.3 \%$ \\
\hline \multirow[t]{2}{*}{ Malir Town } & \multirow{2}{*}{$\begin{array}{l}\text { Rural } \\
\text { Outskirts' } \\
\text { (Group B) }\end{array}$} & \multirow[t]{2}{*}{150} & Memon Goth & 83 & $55.3 \%$ \\
\hline & & & Jam Goth & 67 & $44.6 \%$ \\
\hline $\begin{array}{l}\text { Total } \\
\text { Respondent }\end{array}$ & \multicolumn{2}{|c|}{300} & & 300 & 100 \\
\hline
\end{tabular}

Field survey of household was done in the study area according to laid down criteria that eligible respondent should representative mixture of socio-economic backgrounds. Households were selected for the survey on the basis of the presence of an elder women aged 60 years and above (study population). A structured questionnaire consisting of about 58 questions was used as study tool to collect the data on some important health and social conditions of the elderly. The questionnaire was tested on 18 participants from the same sample population for content validation before it was administered. The participation was voluntary and based on verbal informed consent. The questionnaire comprised socio-demographic details of the participants such as their age, gender, educational level and employment status, followed by research questions. The target study sample was divided into two groups, A and B Group. In group A consisted of senior women belongs to Urban areas whereas, Group B represent the senior women of Rural areas of Karachi. In each group of the study population, the target was to include every section of the society. 


\section{Findings \& Discussion}

A total of 300 elder women were included in this study. The vast majority of the respondents were Muslim, (94.3\%), while the remaining were Christians (6.7\%). Most of the respondents were from lower or middle class / income group. They were either jobless at the time of data collection or had very little income and could not able to meet their financial expenses. In this study, majority of the elderly women from rural study area were illiterate $(32.6 \%)$, majority were married $(32.6 \%)$, and aged 70 and above years old. $35.6 \%$ of the respondents were housewives while $(21.4 \%)$ have been engage in financial responsibilities as Daily wage earner and perhaps this might have been one of the reasons for negligence in their health problems. In both the study areas $26 \%$ of the elderly women were in lower socio-economic group, $70.5 \%$ in middle socio-economic group and only $4 \%$ were in upper socio-economic group.

In a study Pandey and Jha (2011) found that poor economic conditions have a mediating effect on the relationship between widowhood and health. It shows that widowhood has an adverse effect on health - both directly and through reduction in their employment opportunities and economic freedom. It is revealed by this study that elderly women who belongs to 70 and above of the age group have come in the lower socio-economic group (urban $34.6 \%$ vs. rural \%) if the per capita income was also included to assess the SES. This study indicates that women aged between the age group of 60-64 and belongs to urban background were widows only $35.3 \%$ of the women were widows from rural areas of the city.

Table 1

Distribution of Respondents According to Age \& Marital Status

\begin{tabular}{|c|c|c|c|c|c|c|}
\hline $\begin{array}{l}\text { Age Group } \\
\text { in Years }\end{array}$ & $\begin{array}{l}\text { Respondents } \\
\text { Background }\end{array}$ & Single & Married & Widowed & Divorced & Total \\
\hline \multirow[t]{2}{*}{$60-64$} & Women (U) & $\begin{array}{c}29 \\
(19.3 \%)\end{array}$ & $\begin{array}{c}37 \\
(24.6 \%)\end{array}$ & $\begin{array}{c}59 \\
(39.3 \%)\end{array}$ & $\begin{array}{c}25 \\
(16.6 \%)\end{array}$ & 150 \\
\hline & Women (R) & $\begin{array}{c}20 \\
(13.3 \%)\end{array}$ & $\begin{array}{c}50 \\
(33.3 \%)\end{array}$ & $\begin{array}{c}53 \\
(35.3 \%)\end{array}$ & $\begin{array}{c}27 \\
(18.0 \%)\end{array}$ & 150 \\
\hline \multirow[t]{2}{*}{$65-69$} & Women (U) & $\begin{array}{c}22 \\
(14.6 \%) \\
\end{array}$ & $\begin{array}{c}41 \\
(27.3 \%) \\
\end{array}$ & $\begin{array}{c}58 \\
(38.6 \%) \\
\end{array}$ & $\begin{array}{c}29 \\
(19.3 \%) \\
\end{array}$ & 150 \\
\hline & Women (R) & $\begin{array}{c}24 \\
(16.0 \%)\end{array}$ & $\begin{array}{c}47 \\
(31.3 \%)\end{array}$ & $\begin{array}{c}61 \\
(40.6 \%)\end{array}$ & $\begin{array}{c}18 \\
(12.0 \%)\end{array}$ & 150 \\
\hline \multirow[t]{2}{*}{$\begin{array}{l}70 \text { and } \\
\text { above }\end{array}$} & Women (U) & $\begin{array}{c}28 \\
(18.6 \%)\end{array}$ & $\begin{array}{c}46 \\
(30.6 \%)\end{array}$ & $\begin{array}{c}52 \\
(34.6 \%)\end{array}$ & $\begin{array}{c}31 \\
(20.6 \%)\end{array}$ & 150 \\
\hline & Women (R) & $\begin{array}{c}27 \\
(18.0 \%)\end{array}$ & $\begin{array}{c}49 \\
(32.6 \%)\end{array}$ & $\begin{array}{c}52 \\
(34.6 \%)\end{array}$ & $\begin{array}{c}22 \\
(14.6 \%)\end{array}$ & 150 \\
\hline
\end{tabular}


This study shows the sad and bitter scenario of life that during the last two three decades of the end of the life span of many elderly women are spent as widows due to existing socio-cultural factors in the country. In most of the cases this condition is characterized by economic dependence on others or complete destitution.

Table 2

Distribution of Respondents According to their Educational Level

\begin{tabular}{|l|c|c|}
\hline Educational Status & Women (Urban) (\%) & Women (Rural) (\%) \\
\hline Illiterate & $26(17.3 \%)$ & $49(32.6 \%)$ \\
\hline Primary \& Middle & $58(38.6 \%)$ & $24(16.0 \%)$ \\
\hline Matric \& Intermediate & $15(10.0 \%)$ & $02(1.3 \%)$ \\
\hline Graduate \& Above & $14(9.3 \%)$ & $29(19.3 \%)$ \\
\hline Total & $\mathbf{1 5 0}(\mathbf{1 0 0})$ & $\mathbf{1 5 0} \mathbf{( 1 0 0 )}$ \\
\hline
\end{tabular}

Table 3

Distribution of Respondents According to their Family System

\begin{tabular}{|l|c|c|}
\hline Family System & $\begin{array}{c}\text { Respondents Background } \\
\text { Women(Urban ) }\end{array}$ & Women (Rural) \\
\hline Nuclear & $77(51.3 \%)$ & $60(40 \%)$ \\
\hline Extended & $73(48.6 \%)$ & $90(60 \%)$ \\
\hline Total & $\mathbf{1 5 0}$ & $\mathbf{1 5 0}$ \\
\hline
\end{tabular}

In the rural set up $40 \%$ of families were nuclear while only $51.3 \%$ were nuclear families in urban set up.

Table 4

Distribution of Respondents According to their Family Income

\begin{tabular}{|l|c|c|}
\hline Family Income (in Rs.PM) & $\begin{array}{c}\text { Respondents } \\
\text { Background } \\
\text { Women (Urban) }\end{array}$ & $\begin{array}{c}\text { Women } \\
\text { (Rural) }\end{array}$ \\
\hline $\begin{array}{l}\text { Family income } \\
\text { Rs: 10000-12000 }\end{array}$ & $15(10.0 \%)$ & $28(18.6 \%)$ \\
\hline $\begin{array}{l}\text { Family income } \\
\text { Rs: 12,000-14000 }\end{array}$ & $23(15.3 \%)$ & $26(17.3 \%)$ \\
\hline $\begin{array}{l}\text { Family income } \\
\text { Rs: 14000-16000 }\end{array}$ & $26(17.3 \%)$ & $47(31.3 \%)$ \\
\hline $\begin{array}{l}\text { Family income } \\
\text { Rs: } 16000-18000\end{array}$ & $55(36.6 \%)$ & $30(20.0 \%)$ \\
\hline $\begin{array}{l}\text { Family income } \\
\text { Rs: } 18000-\text { and above }\end{array}$ & $31(20.6 \%)$ & $19(12.6 \%)$ \\
\hline Total & $\mathbf{1 5 0}$ & $\mathbf{1 5 0}$ \\
\hline
\end{tabular}


Table 5

Distribution of Respondents According to their Source of Income

\begin{tabular}{|l|c|c|}
\hline $\begin{array}{l}\text { Main Source of } \\
\text { Income }\end{array}$ & $\begin{array}{c}\text { Respondents Background } \\
\text { Women (Urban) }\end{array}$ & Women (Rural) \\
\hline Pension & $15(10.0 \%)$ & $28(18.6 \%)$ \\
\hline Dependent on children & $23(15.3 \%)$ & $26(17.3 \%)$ \\
\hline Business & $19(12.6 \%)$ & $34(22.6 \%)$ \\
\hline Own Laboring & $42(28.0 \%)$ & $38(25.3 \%)$ \\
\hline Property & $51(34.0 \%)$ & $24(16.0 \%)$ \\
\hline Total & $\mathbf{1 5 0}$ & $\mathbf{1 5 0}$ \\
\hline
\end{tabular}

Table 6

Distribution of Respondents by Type of Medical Practitioner Consulted

\begin{tabular}{|l|c|c|}
\hline Type of Medical Practitioner & Women (Urban) (\%) & Women (Rural) (\%) \\
\hline Government doctor & $26(17.3 \%)$ & $49(32.6 \%)$ \\
\hline Private doctor & $58(38.6 \%)$ & $24(16.0 \%)$ \\
\hline Dispenser / paramedical staff & $15(10.0 \%)$ & $02(1.3 \%)$ \\
\hline Hakim / homeopath & $14(9.3 \%)$ & $29(19.3 \%)$ \\
\hline Faith healer & $15(10.0 \%)$ & $22(14.6 \%)$ \\
\hline Medical store & $09(6.0 \%)$ & $11(7.3 \%)$ \\
\hline Self-treated at home & $13(8.6 \%)$ & $15(10.0 \%)$ \\
\hline Total & $\mathbf{1 5 0} \mathbf{( 1 0 0 )}$ & $\mathbf{1 5 0} \mathbf{( 1 0 0 )}$ \\
\hline
\end{tabular}

Regarding the utilization of the services of health centers in urban set-up, very few were availing the services due to lack of medicines, overcrowded hospital environment, shortage of doctors or lack of proper transport facilities and personal help.

Table 7

Distribution of Respondents According to their Social Position in Family Different Situation

\begin{tabular}{|l|c|c|}
\hline Social Position in Family & Women (Urban) (\%) & Women (Rural) (\%) \\
\hline Respect by family members & $23(15.3 \%)$ & $30(20.0 \%)$ \\
\hline Sense of security & $16(10.6 \%)$ & $25(16.6 \%)$ \\
\hline $\begin{array}{l}\text { Family members Daily Sit \& } \\
\text { talk \& spend time with them }\end{array}$ & $14(9.3 \%)$ & $17(11.3 \%)$ \\
\hline Feeling inferior & $25(16.6 \%)$ & $12(8.0 \%)$ \\
\hline Liability on Family & $34(22.6 \%)$ & $38(25.3 \%)$ \\
\hline $\begin{array}{l}\text { Good Relations with } \\
\text { Relatives/ Neighbors }\end{array}$ & $28(18.6 \%)$ & $38(25.3 \%)$ \\
\hline Total & $\mathbf{1 5 0}(\mathbf{1 0 0})$ & $\mathbf{1 5 0 ( 1 0 0 )}$ \\
\hline
\end{tabular}


Table 8

Priority Distribution of Respondents According to Major Categories of Problems Identified by them

\begin{tabular}{|l|c|c|}
\hline Type of Problems & $\begin{array}{c}\text { Women } \\
\text { (Urban) }(\%)\end{array}$ & $\begin{array}{c}\text { Women } \\
\text { (Rural) }(\%)\end{array}$ \\
\hline Financial & $38(25.3 \%)$ & $29(19.3 \%)$ \\
\hline Health & $23(15.3 \%)$ & $33(22.0 \%)$ \\
\hline Housing \& living conditions & $10(6.6 \%)$ & $15(10.0 \%)$ \\
\hline Transport / mobility & $14(9.3 \%)$ & $19(12.6 \%)$ \\
\hline Loneliness & $27(18.0 \%)$ & $16(10.6 \%)$ \\
\hline $\begin{array}{l}\text { Limited Recreational } \\
\text { opportunities/visit outsides }\end{array}$ & $12(8.0 \%)$ & $18(12.0 \%)$ \\
\hline Conflict with son/daughter in Law & $10(6.6 \%)$ & $7(4.6 \%)$ \\
\hline Availability of food on time & $16(10.6 \%)$ & $13(8.6 \%)$ \\
\hline Total & $\mathbf{1 5 0}(\mathbf{1 0 0})$ & $\mathbf{1 5 0}(\mathbf{1 0 0})$ \\
\hline
\end{tabular}

Lack of accessibility to transport was one of the reasons for the elderly women in rural set- up due to which they could not utilize health care services. It was highlighted by elder women that during traveling they faced problems especially when they used public transport. Few respondents shared that most of the bus driver ignore their request for sitting in the bus and they do not stop their buses to pick them and run quickly. It was also shared with great concerns that wash rooms construction are not made according to aged people requirements especially in rural areas. Loneliness was the common psychological distress seen among the study group in both the areas. Nearly all respondents reported having experienced loneliness (urban 18.0\%vs rural 10.6\%) in their elderly period.

\section{Table 9}

\begin{tabular}{|l|c|c|}
\hline \multicolumn{1}{|c|}{ Distribution of Respondents by their Consultation in Family Matters } \\
\begin{tabular}{|l|c|} 
Consultation in the Family \\
Matters
\end{tabular} & $\begin{array}{c}\text { Urban } \\
\text { Yes }\end{array}$ & $\begin{array}{c}\text { Ruler } \\
\text { Yes }\end{array}$ \\
\hline Gift giving & $23(15.3 \%)$ & $32(21.3 \%)$ \\
\hline Purchase of household assets & $15(10 \%)$ & $18(12 \%)$ \\
\hline Purchase of new clothes & $10(6.6 \%)$ & $12(8 \%)$ \\
\hline Purchase of property & $8(5.3 \%)$ & $11(7.3 \%)$ \\
\hline Children's education & $30(20 \%)$ & $21(14 \%)$ \\
\hline Grandchildren's marriage & $41(27.3 \%)$ & $22(14.6 \%)$ \\
\hline Participation in Ceremonies & $23(15.3 \%)$ & $34(22.6 \%)$ \\
\hline Total & $\mathbf{1 5 0 ( 1 0 0 )}$ & $\mathbf{1 5 0}$ \\
\hline
\end{tabular}


More than $25.3 \%$ of the elderly women enjoyed social relations, social interactions and social support mainly from their family members (spouse, children, or in-laws). Any type of community support such as financial assistance, organizations, elderly women's club or provision of raw food items were not available to these woman in either the rural or urban set up. The study indicates that to a large extent support in the form of general care-that is, physical support, financial support, moral support on a regular basis come from spouse, children or in laws. It can be stated that family set up is an important contribution towards healthy and constructive support network. Government assistance was enjoyed by very few elderly women in the study group (only about $10 \%$ were utilizing old age pensions). The study indicated that age is not only an economic and social factor but also leads to physical, medical and psychological disability to a larger extent. The information shows that majority of the respondents in the area feel weaknesses, discomfort and weakness in their old age.

In an analysis Agrawal (2012) found that elderly who are living alone are likely to suffer more from both chronic illnesses, such as asthma and tuberculosis, and acute illnesses, such as malaria and jaundice, than those elderly who are living with their family, even after controlling for the effects of a number of socio-economic, demographic, environmental and behavioural confounders.

Comparing urban and rural respondents pertaining to the categories of problems identified by the respondents, it is reveals that regardless of location (urban vs. rural), women financial (urban $25.3 \%$ vs. rural19.3\%) and health related matters (urban $15.3 \%$ vs rural $22.0 \%$ ) are the major problem of old age. This study confirms that the socio economic and health needs of the elderly are enormous but, unluckily, the financial resources, policies and programmatic capacity available to meet them are insufficient in our society.

\section{Recommendations}

The following recommendations are proposed for different stakeholders to minimize the problems of elder women;

1. All the elderly women opined that they were in need of health and personal care. Strategies should also be developed to create general awareness on the specific problems of the elderly women.

2. Geriatric medicine and gerontological information, as an important component should be introduced in the Medical curriculum: NGOs should be encouraged to take up mobile geriatric services to rural area.

3. Arrangements should be made for providing free physical aids such as spectacles, wheel chair, hearing aids, dentures etc at any time free of cost for elderly women 
especially for widows and for those who belongs to poor socio-economic background. .

4. Keeping in view the existing health care services system, it is suggested that Health Workers should be given training in female geriatric services. Mobile geriatric unit could be more effective as it can cover a large number of aged women especially in rural areas.

5. Health Insurance policy for the elderly woman in rural areas has to be formulated and Rehabilitation of the elderly should be done through integrated community Development Programmes.

6. Day care centers and senior women's club, organizations with recreation facilities should be established in urban and ruler areas.

7. Traditional role of respecting and caring elders should be reinforcing through school level and interventions from the primary level. Elderly women should be given legal security against abuse and harassment.

8. This research recommended that there is a dire need to analyze pressing social issues such as, elder female disrespect and abuse, the gendered nature of age, the changing status of elderly female in society, the politics of power relations between older people and family, state/society and community care.

9. Efforts should be made to provide Free/ concessional medical care facilities at all government hospitals for the elder women. Immunization like Tetanus and Toxoid should be provided free of cost to all the elderly through PHC / Government Hospitals.

10. It is strongly recommended that to develop an inclusive social security program for elder women at grass root level while utilizing tools like value based education, awareness generation, research \& advocacy in order to protect their Rights and our family value system. Public awareness policies should be made in both government and public sector.

\section{Conclusions}

Elderly women and their problems needs special attention as their numbers are likely to increase in the future. The findings of this study highlight the urgency of the need for an effective government policy, which enables a strong partnership between the public and private sectors to ensure implementation of an affective sustainable program as the first step in addressing the socio-economic problems of elder women in Pakistan. It was observed with great concerns; during the period of data collection that Over $50 \%$ of women over age 65 are widows and with the passage of time and rapid changing socioeconomic scenario, industrialization, rapid urbanization, higher aspirations among the youth and the increasing participation of women in the workforce, roots of traditional joint family system has been eroding very fast. The family value concept of traditional joint family system has become thing of past. In such changing situations, majority of 
older women, who have passed most part of their life with their joint/extended families are on the verge of isolation or marginalization in old age. At this age, when they need family support most, they have to live on their own. Even basic needs \& rights of many of them are not addressed. There is a dire need to promote concrete changes in policies, institutions, and practices - both by working with civil society groups and researchers to provide opportunities for public discussion and, where feasible to engage directly with national ministries for the promotion of women and other state agencies and ministries to advocate change and make necessary policies specially for the welfare of older women.

\section{End Note}

1. This ratio is usually estimated as the ratio of the population aged $60 / 65$ years and older to the working age population aged 15-59/64 years, and the inverse of this ratio is called the support ratio. The values of ODR for Pakistan is estimated as .10 in 1998 which compares well with .09 in Bangladesh, .13 in India and .15 in Sri Lanka for the years 2000 (Rajan and others, 2002).

\section{References}

Afzal, Mohammad (1999). Growing Old in Pakistan: Challenges for the New Millennium, UN (United Nations Population Fund).

Agrawal, S. (2012). Effect of Living Arrangement on the Health Status of Older In India, Asian Population Studies, vol. 8, pp. 87-101.

Ali \& Kiani (2003). Ageing and Poverty in Pakistan, Pakistan Institute of Development Economics.

Alam, Hamid., Ali, Farman., Daraz, Umar., Ahmad, Waqar \& Ibrahim. (2013). SocioEconomic Problems of Persons with Old Age in District Dir Lower Khyber Pakhtunkhwa Pakistan, Part-I: Social Sciences and Humanities, volume 4 no. 1 Jan 2013. Available: www.journals.savap.org.pk (accessed 20 March 2014).

Archana Kaushik, (2008). Factors Influencing Sense of Security among Elderly Women, Indian Journal of Gerontology, Vol.22, No.2, pp. 175-195.

Audinarayana, N., 2012, Rural Older in India: Perspectives and Issues, Delhi, B R Publishing Corporation.

Baley, T., Couffinhal, A., Haq, I., Kazi, S., \& Loevinsohn, B. (2010). Pakistan Sector Report: Delivering Better Health Services to Pakistan's Poor, World Bank. 
Bergstrom, M. J., Holmes, M. E., \& Pecchioni, L. (2000). Lay Theories of Successful Ageing after the Death of a Spouse, A Network Text Analysis of Bereavement Advice. Health Communication, 12(4), pp. 377-406.

Women Empowerment, http://www.care.org/work/womens-empowerment, Retrieved on August, 2014.

Gulzar, F., Iqbal, Zafar, M.I., Ahmad, Ashfaq \& Ali, Tanvir, (2008). Socio-Economic Problems of Senior Citizens and their Adjustment in Punjab, Pakistan, Pak. J. Agricultural Sciences., 45(1).

Gapminder. (2011). Available from: http://www.gapminder.org/data/, Accessed Sept 30th 2011.

Government of Pakistan (2002). Ageing in Pakistan: A Situation Analysis, Islamabad, Ministry of Social Welfare and Special Education.

Hage, J. (1972). Techniques and Problems of Theory Construction in Sociology, New York: Wiley Inter science.

Lopez-Claros, A.; Zahidi, S. (2005). Women's Empowerment: Measuring the Global Gender Gap. World Economic Forum, Geneva, Switzerland, www.weforum.org/ pdf/Global_Competitiveness Reports/Reports/gender_gap.pdf, accessed 20 August 2012.

Molyneaux, M. (2003). Gender Justice, Citizenship and Entitlement in Latin America and the Caribbean, IDRC, Ottawa, Canada. Paper Commissioned for the Gender Justice, Citizenship and Entitlement Workshop, Nov. 2003, Ottawa.nd Social Sciences.

Mahmood, N., Nasir, Z. M., \& Pakistan Institute of Development Economics. (2008). Pension and Social Security Schemes in Pakistan: Some Policy Options. Islamabad, Pakistan Institute of Development Economics.

Muhammad, N., Jan, M.A., Shah M. \& Ahmad, Zahoor, (2009). Old Age People: A Socio-Economic View of their Problems in Peshawar City, Pakistan, Pakistan Journal of Life and Social Sciences, 7(2), pp. 126-130.

Pandey, M. K., and A. K. Jha, 2011, Widowhood and Health of Older in India: Examining the Role of Economic Factors Using Structural Equation Modeling: International Review of Applied Economics, vol. 26, pp. 111-124. 
Phillipson, C. \& Baars, J. (2007). Ch. 4: Social Theory and Social Ageing. Ageing in Society (3rd ed.). SAGE, pp. 68-84.

Population Reference Bureau (2005). World Population Data Sheet, http://www.prb.org/pdf05/05worlddatasheet_eng.pdf.

Rehmatullah. (2011). Challenges for Persons with Old Ages, Daily Dawn, October 4, p, 30.

Jalal, S. \& Younis, M. Z. (2012). Ageing and Elderly in Pakistan, http://www.academia. edu/1854670/Aging_and_Elderly_in_Pakistan

Sabzwari \& Azhar, (2010). Ageing in Pakistan-A New Challenge; Ageing International, http://link.springer.com/article/10.1007\%2Fs12126-010-9082-z

Saeed, Y. et.al., (2011). Discrimination and health status of persons with old age in Chakwal: Pakistan, Academic Research International, Volume I issue 3(3).

Saroj et al., (2007). Psycho-social Status of Persons with old age and Related Factors, Department of Human Development \& Family Studies, http://www.krepublishers. com/02-Journals/JHE/JHE-22-0-000-000-2007-Web/JHE-22-3-000-000-2007Abstract-PDF/JHE-22-3-255-07-1578-Saroj/JHE-22-3-255-07-1578-Saroj-Tt.pdf

Saleem, T., Khalid, U., \& Qidwai, W. (2009). Geriatric patients' expectations of their physicians: findings from a tertiary care hospital in Pakistan. BMC Health Services Research, http://www.biomedcentral.com/1472-6963/9/205

Shrestha, L. B. (2000). Population Ageing in Developing Countries, Health Affairs, 19 (3), 204-212, http://content.healthaffairs.org/content/19/3/204.abstract

Sivamurthy \& Wadakannavar, (2001). Care and Support for the Elderly Population in India: Results from a Survey of the Persons with Old Age in Rural North Karnataka, India, Available http://www.silverinnings.com/docs/Ageing Indian.pdf

Strandh, M. (2000). Different Exit Routes from Unemployment and their Impact on Mental Well- Being: The Role of the Economic Situation and the Predictability of the Life Course, Work Employment Society, 14(3), pp. 459-479.

The Holy Quran, 31:14. 
The Situation of Elderly Population in Turkey and National Plan of Action on Ageing, (2007) State Planning Organization, http://www.monitoringris.org/ documents/tools_nat/trk.pdf

United Nations (2004). World Population Prospects: The 2002 Revision. New York, United Nations, Population Division.

UNFPA (2005). State of the World Publication 2005: The Promise of Equality: Gender Equity, Reproductive Health and the Millennium Development Goals, UNFPA, New York, NY, USA.

Violence Against the Elderly, (2011). DAWN Newspaper. Sept 11, 2011. Available at: http://www.dawn.com/2011/09/11/violence-against-the-elderly.html, Accessed August 30, 2011.

World Health Organization. (2005). Addressing violence against women and achieving the Millennium Development Goals. Retrieved May 19, 2008 from http://whqlibdoc.who.int/hq/2005/WHO_FCH_GWH_05.1.pdf.

Zafar, S. N., Ganatra, H. A., Tehseen, S., \& Qidwai, W. (2006). Health and needs assessment of geriatric patients: results of a survey at a teaching hospital in Karachi. Journal of Pakistan Medical Association, 56(10), pp. 470-474.

Dr. Sakina Riaz is Assistant Professor in the Department of Social Work, University of Karachi.

Mahe Darakhshan is Lecturer Department of Media Studies, Bahria University, Karachi.

Samina Rauf is Assistant Professor in the Department of Social Work, University of Karachi. 